GSA DATA REPOSITORY 2015175

\title{
DeCelles and Graham
}

\section{References corresponding to numbers on Figure 2:}

1- Dumitru et al., 2010.

2- Wakabayashi and Dumitru, 2007; Anczkiewicz et al., 2004.

3- Platt, 1986; Jayko et al., 1987; Tagami and Dumitru, 1996; Unruh et al., 2007.

4- Dumitru, 2012; Dumitru et al., 2015; Wakabayashi, 2015.

5- Dickinson, 1995.

6- Williams and Graham, 2013.

7- Mitchell et al., 2010; Dickinson et al., 1979; McGuire, 1988.

8- Unruh et al., 2007.

9- Dickinson et al., 1979.

10- Moxon and Graham, 1987; Williams, 1997; Williams et al., 1998; Williams and Graham, 2013.

11- Constenius et al., 2000; Williams and Graham, 2013.

12- Constenius et al., 2000.

13- Dickinson et al., 1987; this portion of the curve is not back-stripped.

14- Moxon and Graham, 1987.

15- Williams, 1997; Williams and Graham, 2013.

16- Linn et al., 1992.

17- Ingersoll, 1983.

18- Jacobsen et al., 1996; Grove et al., 2003; Kidder and Ducea, 2006.

19- Ducea, 2001; Barton, 1990. 
20- Saleeby and Busby-Spera, 1992.

21- Barton et al., 1988; Barton, 1990; Ducea, 2001; Paterson et al., 2011.

22- Barton et al., 1988; Barton, 1990; Patiño Douce et al., 1990; Howard et al., 2011.

23- Coney and Reynolds, 1977; Dickinson and Snyder, 1978; Constenius, 1996; Bird, 1998.

24- Dunne and Walker, 2004; Hoisch et al., 2014.

25- Speed et al., 1988; Wyld, 2002.

26- Miller et al., 1988; Miller and Gans, 1989; Hodges and Walker, 1992; Smith et al., 1993; Camilleri et al., 1997; Camilleri and McGrew, 1997; McGrew et al., 2000;

Hoisch et al., 2002; Wells and Hoisch, 2008; Wells et al., 2012.

27- Wells and Hoisch, 2008; Wells et al., 2012.

28- Miller et al., 1988; Cooper et al., 2010.

29- Taylor et al., 2000; Druschke et al., 2011.

30- Greene, 2014.

31- Allmendinger et al., 1984.

32- Martin et al., 2010.

33- Vandervoort and Schmitt, 1990.

34- Vandervoort and Schmitt, 1990; Druschke et al., 2009, 2011.

35- Yonkee, 1992; DeCelles et al., 1993; Yonkee et al., 1997, 2013.

36- Armstrong and Oriel, 1965; Royse et al., 1975; Dixon, 1982; Lamerson, 1982;

Wiltshcko and Dorr, 1983; Lawton, 1985; Coogan, 1992; DeCelles, 1994; DeCelles and Mitra, 1995; Yonkee et al., 1997; Lawton et al., 1997; Peyton et al., 2011.

37- Dorr et al., 1977; Lawton, 1983; DeCelles et al., 1987, 1991; Dickinson et al., 1988; 
Brown, 1988; Craddock et al., 1988; Hoy and Ridgway, 1997; Bird, 1998; Fan et al., 2011; Fan and Carrapa, 2014.

38- Barth et al., 2013, based on DeGraaff-Surpless et al., 2002; Wright and Wyld, 2007;

Jacobson et al., 2011; and Grove et al., 2003.

39- Laskowski et al., 2013.

\section{References cited in Figure 2}

Allmendinger, R.W., Miller, D.M., and Jordan, T.E., 1984, Known and inferred Mesozoic deformation in the hinterland of the Sevier belt, northwest Utah, in Kerns, G.J., and Kerns, R.L., editors, Geology of northwest Utah, southern Idaho, and northeast Nevada: Utah Geological Association Publication 13, p. $21-34$.

Anczkiewicz, R., Platt, J.P., Thirlwall, M.F., and Wakabayashi, J., 2004, Franciscan subduction off to a slow start: Evidence from high-precision Lu-Hf garnet ages on high grade-blocks: Earth and Planetary Science Letters, v. 225, p. 147-161, doi:10.1016/j.eps1.2004.06.003.

Armstrong, F.C., and Oriel, S.S., 1965, Tectonic development of Idaho-Wyoming thrust belt: American Association of Petroleum Geologists Bulletin, v. 49, p. 1847-1866.

Barth, A.P., Wooden, J.L., Jacobson, C.E., and Economos, R.C., 2013, Detrital zircon as a proxy for tracking the magmatic arc system: the California arc example: Geology, v. 41, p. $223-226$.

Barton, M.D., Battles, D.A., Bebout, G.E., Capo, R.S., Christensen, J.N., Davis, S.R., Hanson, R.B., Michelsen, C.J., and Trim, H.E., 1988, Mesozoic contact metamorphism in the western United States, in Ernst, W.G., editor, Metamorphism and Crustal 
Evolution of the Western United States, v. 7, p. 110-178, Prentice Hall, Englewood Cliffs, N. J.

Barton, M.D., 1990, Cretaceous magmatism, metamorphism, and metallogeny in the eastcentral Great Basin, in Anderson, J. L., editor, The Nature and Origin of Cordilleran Magmatism: Geological Society of America Memoir 174, p. 283-302.

Bird, P., 1998, Kinematic history of the Laramide orogeny, in latitudes $35^{\circ} 49^{\circ} \mathrm{N}$, western United States: Tectonics, v. 17, p. 780-801.

Brown, W.G., 1988, Deformational style of Laramide uplifts in the Wyoming foreland, in Schmidt, C.J., and Perry, W.J., editors, Interaction of the Rocky Mountain foreland and the Cordilleran thrust belt: Geological Society of America Memoir 171, p. 1-25.

Camilleri, P., and McGrew, A., 1997, Architecture of the Sevier hinterland: a crustal transect through the Pequop Mountains, Wood Hills, and East Humboldt Range, Nevada, in Link, P.K., and Kowallis, B.J., editors, Proterozoic to Recent Stratigraphy, Tectonics, and Volcanology, Utah, Nevada, Southern Idaho and Central Mexico: Brigham Young University Geology Studies, v. 42, part 1, p. 310-324.

Camilleri, P., Yonkee, W.A., Coogan, J.C., DeCelles, P.G., McGrew, A., and Wells, M., 1997, Hinterland to foreland transect through the Sevier orogen, NE Nevada to SW Wyoming: structural style, metamorphism, and kinematic history of a large contractional orogenic wedge, in Link, P.K., and Kowallis, B.J., eds., Brigham Young University Geology Studies: v. 42, part 1, p. 297-309.

Coney, P.J., and Reynolds, S.J., 1977, Cordilleran Benioff zones, Nature, v. 270, p. 403406, doi:10.1038/270403a0.

Constenius, K.N., 1996, Late Paleogene extensional collapse of the Cordilleran foreland 
fold and thrust belt: Geological Society of America Bulletin, v. 108, p. 20-39.

Constenius, K.N., Johnson, R.A., Dickinson, W.R., Williams, T.A., 2000, Tectonic evolution of the Jurassic-Cretaceous Great Valley forearc, California: Implications for the Franciscan thrust-wedge hypothesis: Geological Society of America Bulletin, v. 112, p. $1703-1723$.

Coogan, J.C., 1992, Structural evolution of piggyback basins in the Wyoming-IdahoUtah thrust belt, in Link, P.K., Kuntz, M.A., and Platt, L.B., editors, Regional Geology of Eastern Idaho and Western Wyoming: Geological Society of America Memoir 179, p. $55-81$.

Cooper, F. J., Platt, J.P., Anczkiewicz, R., and Whitehouse, M.J., 2010, Footwall dip of a core complex detachment fault: Thermobarometric constraints from the northern Snake Range (Basin and Range, USA): Journal of Metamorphic Geology, v. 28, p. 997-1020, doi:10.1111/j.1525-1314.2010.00907.x.

Craddock, J.P., Kopania, A.A., and Wiltschko, D.V., 1988, Interaction between the northern Idaho-Wyoming thrust belt and bounding basement blocks, central western Wyoming, in Schmidt, C.J., and Perry, W.J., Jr., editors, Interaction of the Rocky Mountain foreland and the Cordilleran thrust belt: Geological Society of America Memoir 171, p. 333-351.

DeCelles, P.G., 1994, Late Cretaceous-Paleocene synorogenic sedimentation and kinematic history of the Sevier thrust belt, northeast Utah and southwest Wyoming: Geological Society of America Bulletin, v. 106, p. 32-56.

DeCelles, P. G., Tolson, R. G., Graham, S. A., Smith, G. A., Ingersoll, R. V., White, J., Schmidt, C. J., Rice, R., Moxon, I., Lemke, L., Handschy, J. W., Follo, M. F., Edwards, 
D. P., Cavazza, W., Caldwell, M., and Bargar, E., 1987, Laramide thrust-generated alluvial-fan sedimentation, Sphinx Conglomerate, southwestern Montana: American Association of Petroleum Geologists Bulletin, v. 71, p. 135-155.

DeCelles, P. G., Gray, M. B., Ridgway, K. D., Cole, R. B., Srivastava, P., Pequera, N., and Pivnik, D. A., 1991, Kinematic history of foreland uplift from Paleocene synorogenic conglomerate, Beartooth Range, Wyoming and Montana: Geological Society of America Bulletin, v. 103, p. 1458-1475.

DeCelles, P. G., Pile, H. T., and Coogan, J. C., 1993, Kinematic history of the Meade thrust based on provenance of the Bechler Conglomerate at Red Mountain, Idaho, Sevier thrust belt: Tectonics, v. 12, p. 1436-1450.

DeCelles, P.G. and Mitra, P. G., 1995, History of the Sevier orogenic wedge in terms of critical taper models, northeast Utah and southwest Wyoming: Geological Society of America Bulletin, V. 107, p. 454-462.

DeGraaff-Surpless, K., Graham, S.A., Wooden, J.L., and McWilliams, M.O., 2002, Detrital zircon provenance analysis of the Great Valley Group, California: Evolution of an arc-forearc system: Geological Society of America Bulletin, v. 114, p. 1564-1580, doi:10.1130/0016- 7606(2002)114<1564:DZPAOT>2.0.CO;2.

Dickinson, W.R., 1995, Forearc Basins, in Ingersoll, R. V., and Busby, C. J., editors, Tectonics of Sedimentary Basins, p. 221-261.

Dickinson, W. R., and Snyder, W. S., 1978, Plate tectonics of the Laramide orogeny, in Matthews, V., editor, Laramide folding associated with block faulting in the western United States: Geological Society of America Memoir 151, p. 355-366.

Dickinson, W.R., Ingersoll, R.V., and Graham, S.A., 1979, Paleogene sediment dispersal 
and paleotectonics in northern California: Geological Society of America Bulletin, v. 90, summary in Part I, p. 897-898, text in Part II, p. 1458-1528.

Dickinson, W.R., Armin, R.A., Beckvar, N., Goodlin, T.C., Janecke, S.U., Mark, R.A., Norris, R.D., Radel, G., and Wortman, A.A., 1987, Geohistory Analysis of Rates of Sediment Accumulation and Subsidence for Selected California Basins, in Ingersoll, R.V., and Ernst, W.G., editors, Cenozoic Basin Development of Coastal California, Prentice Hall, Englewood Cliffs, NJ, p. 1-23.

Dickinson, W.R., Klute, M.A., Hayes, M.J., Janecke, S.U., Lundin, E.R., McKittrick, M.A., and Olivares, M.D., 1988, Paloeogeographic and paleotectonic setting of Laramide sedimentary basins in the central Rocky Mountain region: Geological Society of America Bulletin, v. 100, p. 1023-1039.

Dixon, J.S., 1982, Regional structural synthesis, Wyoming salient of the western Overthrust Belt: American Association of Petroleum Geologists Bulletin, v. 10, p. $1560-1580$.

Dorr, J.A., Spearing, D.R., and Steidtmann, J.R., 1977, Deformation and deposition between a foreland uplift and an impinging thrust belt: Hoback Basin, Wyoming: Geological Society of America Special Paper 177, 82 p.

Druschke, P., Hanson, A.D., and Wells, M.L., 2009, Structural, stratigraphic, and geochronologic evidence for extension predating Palaeogene volcanism in the Sevier hinterland, east-central Nevada: International Geology Review, v. 51, p. 743-775.

Druschke, P., Hanson, A.D., Wells, M.L., Gehrels, G.E., and Stockli, D., 2011, Paleogeographic isolation of the Cretaceous to Eocene Sevier hinterland, east-central Nevada: Insights from $\mathrm{U}-\mathrm{Pb}$ and (U-Th)/He detrital zircon ages of hinterland strata: 
Geological Society of America Bulletin, v. 123, p. 1141-1160, doi:10.1130/B30029.1.

Ducea, M., 2001, The California arc: thick granitic batholiths, eclogitic residues, lithospheric-scale thrusting, and magmatic flare-ups: GSA Today, v. 11, p. 4-10.

Dumitru, T.A., 2012, New, much younger ages for the Yolla Bolly terrane and a revised timeline for accretion in the Franciscan subduction complex, California: American Geophysical Union Fall Meeting, Abstract, p. T11A-2543.

Dumitru, T.A., Wakabayashi, J., Wright, J.E., and Wooden, J.L., 2010, Early Cretaceous (ca. $123 \mathrm{Ma}$ ) transition from nonaccretionary behavior to strongly accretionary behavior within the Franciscan subduction complex: Tectonics, v. 29, DOI: $10.1029 / 2009$ TC002542.

Dumitru, T.A., Ernst, W.G., Hourigan, J.K., and McLaughlin, R.J., 2015, Detrital zircon $\mathrm{U}-\mathrm{Pb}$ reconnaissance of the Franciscan subduction complex in northwestern California: International Geology Review, DOI:10.1080/00206814.2015.1008060.

Dunne, D.C., and Walker, J.D., 2004, Structure and evolution of the East Sierran thrust system, east central California: Tectonics, v. 23, TC4012, doi:10.1029/2002TC001478.

Fan, M., Quade, J., Dettman, D.L., DeCelles, P.G., 2011, Widespread basement erosion in late Paleocene-early Eocene in the Laramide Rocky Mountains inferred from ${ }^{87} \mathrm{Sr} /{ }^{86} \mathrm{Sr}$ ratio of bivalve fossils: Geological Society of America Bulletin, v. 123, p. 2069-2082.

Fan, M., and Carrapa, B., 2014, Late Cretaceous-early Eocene Laramide uplift, exhumation, and basin subsidence in Wyoming: Crustal responses to flat slab subduction: Tectonics, v. 33, doi:10.1002/2012TC003221.

Greene, D.C., 2014, The Confusion Range, west-central Utah: Fold-thrust deformation 
and a western Utah thrust belt in the Sevier hinterland: Geosphere, v. 10, p. 148-169.

Grove, M., Jacobson, C.E., Barth, A.P., and Vucic, A., 2003, Temporal and spatial trends of Late Cretaceous-Early Tertiary underplating of Pelona and related schists beneath southern California and southwestern Arizona, in Johnson, S.E., et al., editors, Tectonic Evolution of Northwestern Mexico and the Southwestern USA: Geological Society of America Special Paper 374, p. 381-406.

Hodges, K.V., and Walker, J.D., 1992, Extension in the Cretaceous Sevier orogen, North American Cordillera: Geological Society of America Bulletin, v. 104, p. 560-569.

Hoisch, T.D., Wells, M.L., and Hanson, L.M., 2002, Pressure-temperature paths from garnet-zoning: Evidence for multiple episodes of thrust burial in the hinterland of the Sevier orogenic belt: American Mineralogist, v. 87, p. 115-131.

Hoisch, T.D., Wells, M.L., Beyene, M.A., Styger, S., and Vervoort, J.D., 2014, Jurassic Barrovian metamorphism in a western U.S. Cordilleran metamorphic core complex, Funeral Mountains, California: Geology, v. 42, p. 399-402.

Howard, K.A., Wooden, J.L., Barnes, C.G., Premo, W.R., Snoke, A.W., and Lee, S.Y., 2011, Episodic growth of a Late Cretaceous and Paleogene intrusive complex of pegmatitic leucogranite, Ruby Mountains core complex, Nevada, U.S.A.: Geological Society of America Bulletin, v. 7, p. 1220-1248, doi:10.1130/GES00668.1.

Hoy, R.G., and Ridgway, K.D., 1997, Structural and sedimentologic development of footwall growth synclines along an intraforeland uplift, east-central Bighorn Mountains, Wyoming: Geological Society of America Bulletin, v. 109, p. 915-935. Ingersoll, R. V., 1983, Petrofacies and provenance of late Mesozoic forearc basin, northern and central California: American Association of Petroleum Geologists 
Bulletin, v. 67, p. 1125-1142.

Jacobson, C.E., Oyarzabal, F.R., and Haxel, G.B., 1996, Subduction and exhumation of the Pelona-Orocopia-Rand schists, southern California: Geology, v. 24, p. 547-550.

Jacobson, C.E., Grove, M., Pedrick, J.N., Barth, A.P., Marsaglia, K.M., Gehrels, G.E., and Nourse, J.A., 2011, Late Cretaceous-early Cenozoic tectonic evolution of the southern California margin inferred from provenance of trench and forearc sediments:

Geological Society of America Bulletin, v. 123, p. 485-506, doi:10.1130/B30238.1.

Jayko, A.S., Blake, M.C., Jr., and Harms, T., 1987, Attenuation of the Coast Range

Ophiolite by extensional faulting, and the nature of the Coast Range " thrust,"

California: Tectonics, v. 6, p. 475-488.

Kidder, S., and Ducea, M.N., 2006, High temperatures and inverted metamorphism in the schist of Sierra de Salinas, California: Earth and Planetary Science Letters, v. 241, p. 422-437.

Lamerson, P.R., 1982, The Fossil Basin and its relationship to the Absaroka thrust system, Wyoming and Utah, in Powers, R. B., editor, Geologic studies of the Cordilleran thrust belt: Denver, Colorado, Rocky Mountain Association of Geologists, p. 279-337.

Laskowski, A.K., DeCelles, P.G., and Gehrels, G.E., 2013, Detrital geochronology of Cordilleran retroarc foreland basin strata, western North America: Tectonics, v. 32, doi:10.1002/tect.20065.

Lawton, T.F., 1983, Late Cretaceous fluvial systems and the age of foreland uplifts in central Utah, in Lowell, J.D., editor, Rocky Mountain foreland basins and uplifts: Denver, Colorado, Rocky Mountain Association of Geologists, p. 181-199. 
Lawton, T.F., 1985, Style and timing of frontal structures, thrust belt, central Utah:

American Association of Petroleum Geologists Bulletin, v. 69, p. 1145-1159.

Lawton, T.F., Sprinkel, D., DeCelles, P.G., Mitra, G., and Sussman, A.J., 1997, Thrusting and synorogenic sedimentation in the central Utah Sevier thrust belt and foreland basin, in Link, P. K., and Kowallis, B.J., editors, Mesozoic to Recent geology of Utah:

Brigham Young University Geology Studies, v. 42, part 2, p. 33-67.

Linn, A.M., DePaolo, D.J., and Ingersoll, R.V., 1992, Nd-Sr isotopic, geochemical, and pétrographie stratigraphy and paleotectonic analysis: Mesozoic Great Valley forearc sedimentary rocks of California: Geological Society of America Bulletin, v. 104, p. 1264-1279.

Martin, A.J., Wyld, S.J., Wright, J.E., and Bradford, J.H., 2010, The Lower Cretaceous King Lear Formation, northwest Nevada: Implications for Mesozoic orogenesis in the western U.S. Cordillera: Geological Society of America Bulletin, v. 122, p. 537-562, doi:10.1130/B26555.1.

McGrew, A.J., Peters, M.T., and Wright, J.E., 2000, Thermobarometric constraints on the tectonothermal evolution of the East Humboldt Range metamorphic core complex, Nevada: Geological Society of America Bulletin, v. 112, p. 45-60.

McGuire, D.J., 1988, Stratigraphy, depositional history and hydrocarbon source-rock potential of the Upper Cretaceous-Lower Tertiary Moreno Formation, central San Joaquin basin, California: Ph.D. Dissertation, Stanford University, 231 p.

Miller, E.L., Gans, P.B., Wright, J.E., and Sutter, J.F., 1988, Metamorphic history of the east-central Basin and Range province: tectonic setting and relationship to magmatism, in Ernst, W. G., editor, Metamorphism and crustal evolution, western conterminous 
United States, Rubey Volume VII: Englewood Cliffs, New Jersey, Prentice-Hall, p. 649-682.

Miller, E.L., and Gans, P.B., 1989, Cretaceous crustal structure and metamorphism in the hinterland of the Sevier thrust belt, western U.S. Cordillera: Geology, v. 17, p. 59-62.

Mitchell, C., Graham, S.A., and Suek, D.H., 2010, Subduction complex uplift and exhumation and its influence on Maastrichtian forearc stratigraphy in the Great Valley Basin, northern San Joaquin Valley, California: Geological Society of America Bulletin, v. 122, p. 2063-2078.

Moxon, I.W., and Graham, S.A., 1987, History and controls of subsidence in the Late Cretaceous-Tertiary Great Valley forearc basin, California: Geology, v. 15, p. 626629.

Paterson, S.R., Okaya, D., Memeti, V., Economos, R., and Miller, R.B., 2011, Magma addition and flux calculations of incrementally constructed magma chambers in continental margin arcs: Combined field, geochronologic, and thermal modeling studies: Geosphere, v. 7, p. 1439-1468, doi:10.1130/GES00696.1.

Patiño Douce, A.E., Humphreys, E.D. and Johnston, A.D., 1990, Anatexis and metamorphism in tectonically thickened continental crust exemplified by the Sevier hinterland, western North America: Earth and Planetary Science Letters, v. 97, p. 290315, doi:10.1016/0012-821X(90)90048-3.

Peyton, S.L., Constenius, K.N., and DeCelles, P.G., 2011, Early eastward translation of shortening in the Sevier thrust belt, northeast Utah and southwest Wyoming, U.S.A., in Sprinkel, D.A., Yonkee, W.A., and Chidsey, T.C., Jr., editors, Sevier thrust belt: 
northern and central Utah and adjacent areas: Utah Geological Society Special Publication, v. 40, p. 57-72.

Platt, J.P., 1986, Dynamics of orogenic wedges and the uplift of high-pressure metamorphic rocks: Geological Society of America Bulletin, v. 97, p. 1037-1053.

Royse, F., Jr., Warner, M.A., and Reese, D.L., 1975, Thrust belt structural geometry and related stratigraphic problems Wyoming-Idaho-northern Utah, in Bolyard, D. W., editor, Deep drilling frontiers of the central Rocky Mountains: Denver, Rocky Mountain Association of Geologists, p. 41-54.

Saleeby, J. B., and Busby-Spera, C., 1992, Early Mesozoic tectonic evolution of the western U.S. Cordillera, in Burchfiel, B. C., Lipman, P. W., and Zoback, M. L., editors, The Cordilleran Orogen: Conterminous U. S.: Geological Society of America, The Geology of North America, v. G-3, p. 107-168.

Smith, D.L., Miller, E.L., Wyld, S.J., and Wright, J.E., 1993, Progression and timing of Mesozoic crustal shortening in the northern Great Basin, western U.S.A., in Dunn, G., and McDougall, K., editors, Mesozoic Paleogeography of the Western United StatesII Pacific section: Society of Economic Paleontologists and Mineralogists, Book 71, p. $389-406$.

Speed, R. C., Elison, M. W., and Heck, R. R., 1988, Phanerozoic tectonic evolution of the Great Basin, in Ernst, W. G., editor, Metamorphism and crustal evolution of the western United States, Rubey Volume 7: Englewood Cliffs, New Jersey, Prentice-Hall, p. 572-605. 
Tagami, T., and Dumitru, T.A., 1996, Provenance and thermal history of the Franciscan accretionary complex: constraints from zircon fission track thermochronology: Journal of Geophysical Research, v. 101, p. 11,353-11,364.

Taylor, W.J., Bartley, J.M., Martin, M.W., Geismann, J.W., Walker, J.D., Armstrong, P.A., and Fryxell, J.E., 2000, Relations between hinterland and foreland shortening: Sevier orogeny, central North American Cordillera: Tectonics, v. 19, p. 1124-1143.

Unruh, J.R., Dumitru, T.A., and Sawyer, T.L., 2007, Coupling of early Tertiary extension in the Great Valley forearc basin with blueschist exhumation in the underlying Franciscan accretionary wedge at Mount Diablo, California: Geological Society of America Bulletin, v. 119, p. 1347-1367.

Vandervoort, D.S., and Schmitt, J.G., 1990, Cretaceous to early Tertiary paleogeography in the hinterland of the Sevier thrust belt, east-central Nevada: Geology, v. 18, p. 567570.

Wakabayashi, J., 2015, Anatomy of a subduction complex: architecture of the Franciscan Complex, California, at multiple length and time scales: International Geology Review, DOI: 10.1080/00206814.2014.998728.

Wakabayashi, J., and Dumitru, T.A., 2007, ${ }^{40} \mathrm{Ar} /{ }^{39} \mathrm{Ar}$ ages from coherent, high -pressure metamorphic rocks of the Franciscan Complex, California: Revisiting the timing of metamorphism of the world's type subduction complex: International Geological Review, v. 49, p. 873-906, doi:10.2747/0020-6814.49.10.873.

Wells, M. L., and Hoisch, T.D., 2008, The role of mantle delamination in widespread Late Cretaceous extension and magmatism in the Cordilleran orogen, Western US: Geological Society of America Bulletin, v. 120, p. 515-530, doi:10.1130/ B26006.1. 
Wells, M.L., Hoisch, T.D., Cruz-Uribe, A.M., Vervoort, J.D., et al., 2012, Geodynamics of synconvergent extension and tectonic mode switching: Constraints from the SevierLaramide orogen: Tectonics, v. 31, doi:10.1029/2011TC002913.

Williams, T.A., 1997, Basin-fill architecture and forearc tectonics, Cretaceous Great Valley Group, Sacramento basin, northern California [Ph.D. thesis]: Stanford, California, Stanford University, 412 p.

Williams, T.A., Graham, S.A., and Constenius, K.N., 1998, Recognition of a Santonian submarine canyon, Great Valley Group, Sacramento basin, California: Implications for petroleum exploration and sequence stratigraphy of deep-marine strata, American Association of Petroleum Geologists Bulletin, v. 82, p. 1575-1595.

Williams, T.A., and Graham, S.A., 2013, Controls on forearc basin architecture from seismic and sequence stratigraphy of the Upper Cretaceous Great Valley Group, central Sacramento Basin, California: International Geology Review, v. 55, p. 2030-2059. Wiltschko, D.V., and Dorr, J.A., 1983, Timing of deformation in overthrust belt and foreland of Idaho, Wyoming and Utah: American Association of Petroleum Geologists Bulletin, v. 67, p. 1304-1322.

Wright, J.E., and Wyld, S.J., 2007, Alternative tectonic model for Late Jurassic through Early Cretaceous evolution of the Great Valley Group, California, in Cloos, M., et al., editors, Convergent margin tectonics and associated regions: Geological Society of America Special Paper 419, p. 81-95.

Wyld, S. J., 2002, Structural evolution of a Mesozoic backarc fold-and-thrust belt in the U.S. Cordillera: new evidence from northern Nevada: Geological Society of America Bulletin, v. 114, p. 1452-1468. 
Yonkee, W. A., 1992, Basement-cover relations, Sevier orogenic belt, northern Utah: Geological Society of America Bulletin, v. 104, p. 280-302.

Yonkee, W. A., DeCelles, P. G., and Coogan, J. C., 1997, Kinematics and synorogenic sedimentation of the eastern frontal part of the Sevier orogenic wedge, northern Utah, in Link, P. K., and Kowallis, B. J., editors, Proterozoic to Recent Stratigraphy, Tectonics, and Volcanology, Utah, Nevada, Southern Idaho and Central Mexico: Brigham Young University Geology Studies, v. 42, part 1, p. 355-380

Yonkee, A., Weil, A.B., and Mitra, G., 2013, Transect of the Sevier and Laramide orogenic belts, northern Utah to Wyoming: Evolution of a complex geodynamic system, in Abbott, L.D., and Hancock, G.S., editors, Classic Concepts and New Directions: Exploring 125 Years of GSA Discoveries in the Rocky Mountain Region: Geological Society of America Field Guide 33, p. 1-55, doi:10.1130/2013.0033(03). 